\title{
EVALUATION OF STUDENTS' PERCEPTIONS OF ONLINE-BASED SCIENCE LEARNING MATERIALS DURING THE COVID-19 PANDEMIC AT SMP IT KHAIRUNNAS, BENGKULU CITY
}

Ega Arya Saputra ${ }^{1}$, Ikmi Marlina $^{2}$, Nur Azizah $^{3}$, Ogi Saputra ${ }^{4}$, Ahmad Walid $^{5}$

1,2,3,4,5 Natural Science Education, Fatmawati Soekarno State Islamic University Bengkulu Email: ahmadwalid@iainbengkulu.ac.id

\begin{abstract}
This study aims to determine the perception of students' understanding of science material at SMP IT KHAIRUNNAS Bengkulu City during the covid-19 pandemic or during face-to-face learning. The method used in this research is using a qualitative method. The data analysis technique used is descriptive qualitative technique. The results showed that students' perceptions of science learning during the covid 19 pandemic at SMP IT KHAIRUNNAS Bengkulu City showed that on average students were more aware of learning during face-to-face learning compared to online learning, because online learning was considered difficult because the science material presented by the teacher was lacking. Obviously, students also have difficulty understanding the formula from the explanation without being written directly by the teacher on the blackboard, when faceto-face learning makes it easier to explain material and answer questions given by the teacher.
\end{abstract}

\section{Keywords: Covid-19 pandemic, evaluation, face-to-face, online learning}

This work is licensed under Creative Commons Attribution License 4.0 CC-BY International license

\section{INTRODUCTION}

\subsection{Introduction}

The 21st century is now marked as the century of openness or the century of globalization, meaning that human life in the 21 st century undergoes fundamental changes that are different from the way of life in the previous century. As is well known in the 21st century, there has been a total change in both society and the world of education. Schools that are understood to date have been formed since the 19th century in the context of developing children's education and also encouraging industrialization, especially the current covid-19 pandemic. To prevent the spread of COVID-19 at this time, it is recommended to stop events that will invite crowds. Therefore, faceto-face learning will gather many students in a class during the lecture process.

Therefore, a scenario is held that can prevent physical relations between students and lecturers (Firman, F \& Rahayu, S. 2020). So the solution during the COVID-19 pandemic is online 
learning. According to (Moore, Dickson-Deane \& Galyen. 2011) online learning is learning that uses the internet network with accessibility, connectivity, flexibility, and the ability to bring up various types of learning interactions. Online learning is not only with the internet, but an important aspect is that it is safer for us to know Learning Management Systems (LMS) (Ali, Gunay Balim. 2009)

Evaluation (assessment) is a process of collecting, reporting and using information about student learning outcomes obtained through measurement with the aim of analyzing or explaining student achievement in carrying out related tasks and making effective use of this information to achieve educational goals (Puskur, 2002). The impact of the global pandemic began to penetrate the world of education in Indonesia, until in the end the central government gave a policy to close all educational institutions in Indonesia. This is done as an effort to prevent the spread of the Covid19 virus.

\subsection{Research questions}

How are students' perceptions of online science learning in the era of the covid-19 pandemic at SMP IT KHAIRUNNAS Bengkulu City?

\subsection{Significance of the study}

With government policies that replace educational activities, it makes the government and related institutions to present alternatives as an educational process for students who are unable to carry out the educational process at related institutions. So finally, the distance learning method or online (E-learning Class) was taken as a step to continue to be able to carry out the learning process by utilizing existing online learning applications such as Edmodo, Google Classroom, Zoom and so on (Kemendikbud, 2020). In the current study, we want to compare whether students of SMP IT KHAIRUNNAS Bengkulu City can understand and understand learning, especially science lessons online through existing media or better offline, and also we want to know whether online science learning is effective or not.

\section{RESEARCH METHODS}

\subsection{Research Design}

The research used is descriptive qualitative research by collecting data based on research or surveys directly to SMP IT KHAIRUNNAS Bengkulu city and we also use online research because considering that currently the spread of covid 19 is still rampant in Indonesia. The 
supporting data used in this study are articles, documents, books or news related to the evaluation of learning during the COVID-19 pandemic.

\subsection{Population and Sample}

The population in this study amounted to 3 classes, each consisting of class A totaling 14 people, class B totaling 12 people, and class C totaling 12 people at SMP IT KHAIRUNNAS Bengkulu City. The question and answer interview technique is used to take samples for the data collection process. In this case, 38 students per class volunteered in the survey. In addition, teachers are also involved in helping in data collection. The decision to involve teachers in this study was taken to build on existing findings regarding the impact of online learning at school during the covid 19 pandemic.

\subsection{Data Collection Instrumen}

The data collection techniques used are: 1. observation, 2. interviews, 3. analyzing material, data collection is the method used to collect information or facts in the field based on a survey conducted.

\subsection{Data Analysis}

Qualitative research is research that collects data that has been analyzed. This qualitative is considered relevant to condition what happens in online learning during the pandemic. The type of data collected is the result of research from observations and interviews. Subjects and objects in this study were students and teachers in the science department interacting with each other to observe questions and answers (Sugiyono, 2009).

\section{FINDINGS AND DISCUSSION}

\subsection{Findings}

For approximately 2 years the spread of the covid 19 virus, schools conducted online learning including SMP IT KHAIRUNNAS Bengkulu City, the media that were often used based on the results of our interviews at the junior high school were the WA, Zoom and Google Classroom applications, which were used as supporting media. However, this online learning media is considered less effective by students and teachers because there are so many obstacles in the online learning media such as the lack of an adequate network, the material conveyed by the teacher is not clear, the tasks piled up which are not direct. done by students and the number of 
students who do not take part in learning when zooming or during discussions on wa or google classroom because of oversleeping and so on.

During the pandemic a lot of students at SMP IT KHAIRUNNAS Bengkulu City hoped to do face-to-face learning because based on our research on students at the junior high school, faceto-face learning is considered more effective because students understand more about the material delivered by the science teacher so that there are students who understand science formulas and science material that is conveyed face-to-face when learning online is very different, during UTS and UAS also students at SMP IT KHAIRUNNAS Bengkulu City prefer face-to-face because it is more effective because Pother students can't find answers on the internet when UTS and UAS are face-to-face, different when online, many students answer UTS and UAS questions by looking for answers on the internet, and another reason that we find a lot is that students don't like to study online because they can't meet their classmates.

One of the steps taken by science teachers so that the learning process can continue and not burden students is to use zoom, power point and video media. The selection of the zoom application is effective because it allows teachers and students to meet face to face even though they are far apart. And usually teachers use the wa application to send learning materials and assignments to make it easier for students and teachers in the learning process. The hope of science teachers when studying online is that teachers can freely write science learning materials such as formulas and so on, and students can be more active in listening to lessons.

Based on the results of research and interviews that we did at SMP IT KHAIRUNNAS Bengkulu city, we got the results of interviews from 3 rooms from class V1ll, totaling 36 students from class V1ll A, Class V1ll B and class V1l C and also we conducted interviews with teachers science online and face-to-face to determine the effectiveness of students in learning and understanding science material delivered by teachers during online learning and during face-toface learning.

Table 1. Evaluation table for students' understanding perception of class VIII SMP IT KHAIRUNNAS Bengkulu City during online or face-to-face learning.

\begin{tabular}{|c|c|c|c|c|}
\hline \multirow[t]{2}{*}{ No. } & \multirow{2}{*}{$\begin{array}{l}\text { Class } \\
\text { VIII }\end{array}$} & \multirow{2}{*}{$\begin{array}{l}\text { number of class } \\
\text { students VIII }\end{array}$} & \multicolumn{2}{|c|}{$\begin{array}{l}\text { Perceptions of which students choose more } \\
\text { effective online or face-to-face learning }\end{array}$} \\
\hline & & & Online Learning & $\begin{array}{l}\text { Face-to-face } \\
\text { Learning }\end{array}$ \\
\hline 1. & VIII A & 14 Person & There is not any & 14 Person \\
\hline 2. & VIII B & 12 Person & 2 Person & 10 Person \\
\hline 3. & VIII C & 12 Person & There is not any & 12 Person \\
\hline
\end{tabular}




\subsection{Discussion}

From the data above, it shows that on average students are more effective in their perception of learning understanding when face-to-face learning is compared to online learning, because online learning is considered difficult because the science material presented by the teacher is not clear, students also have difficulty understanding the formula from the explanation without being written in writing. directly by the teacher on the blackboard, when face-to-face learning makes it easier to explain the material and answer the questions given by the teacher.

Online and face-to-face learning will run smoothly if the supporting factors are met. Based on the results of interviews we conducted with students and teachers at SMP IT KHAIRUNNAS Bengkulu City, the supporting factors for student success when learning online are a stable internet connection, adequate internet quota, communication tools such as cellphones and laptops, there must be interest and motivation of students, as well as the role of teachers and parents.

Based on the results of the interviews above, it was found that the supporting factors in implementation of online and face-to-face learning on science subjects at SMP IT KHAIRUNNAS Bengkulu City. Factors that support online learning include learning facilities (smartphones) and internet networks. Online learning can be said as learning in an environment using devices such as mobile phones and laptops with internet access as a support (Singh \& Thurman, 2019). While the supporting factors for face-to-face learning are blackboards, books, praga tools, and direct interaction of students and teachers. Face-to-face learning is considered by students to make it easier for the teacher to deliver the material and students also understand more about science material if it is explained directly.

According to Gikas \& Grant (2013), online learning requires the support of mobile devices to access information anywhere and anytime, such as: smartphones, tablets and laptops. Purwanto, et al. (2020) stated that the importance of facilities such as laptops, computers or mobile phones for the smooth process of online teaching and learning. These facilities make it easier for teachers to provide learning materials. In order to maximize the supporting factors, teachers can look for learning media in the form of videos and continue to follow developments or progress students in participating in online learning reported by parents via Whatsapp groups. Teachers can provide information or things that are asked by students in learning.

We conducted an evaluation at SMP IT KHAIRUNNAS Bengkulu city when the teacher was not in class and when the class was empty so that the results of the interviews we conducted at the junior high school were effective and we also conducted research every day for 
approximately one week, because at this time Face-to-face learning has run smoothly again. Currently, students and teachers are required to vaccinate to reduce the spread of the COVID-19 virus so that we can conduct research at SMP IT KHAIRUNNAS, Bengkulu City.

\section{CONCLUSION}

\subsection{Conclusion}

Based on the results of research that has been done regarding the effectiveness of online learning during the covid-19 pandemic in class VIII SMP IT KHAIRUNNAS Bengkulu City, it was found that during online lessons there were many students who were less active in the learning process and most students tended to feel bored because besides they feel they don't understand about the explanation of the material they have also been negligent of the tasks given by the teacher and also they have started acting a lot like truant during class hours, falling asleep, some even don't care about the online lessons given by the teacher.

In addition to the unclear material, students at SMP IT KHAIRUNNAS Bengkulu City are also often hampered by their online learning process due to various obstacles such as loss of signal during the learning process, then students fall asleep during lessons and there are even students who do not participate in learning at all. One of the steps taken by science teachers so that the learning process can continue and not burden students is to use zoom, power point and video media. The selection of the zoom application is effective because it allows teachers and students to meet face to face even though they are far apart. And usually teachers use the wa application to send learning materials and assignments to make it easier for students and teachers in the learning process. Therefore, in essence, students are more effective in understanding their learning when face-to-face learning is compared to online learning, because online learning is considered difficult because the science material presented by the teacher is not clear, students also have difficulty understanding the formula of the explanation without written explanation of the material and answer the questions given by the teacher. We and students hope that online learning activities are immediately stopped and that face-to-face learning is carried out immediately so that no more children are negligent in their duties and even neglect the school and the learning process.

\subsection{Suggestion}

In writing this article the researcher realizes that there are still many shortcomings, both in the form of theory, and other internal factors. Therefore, researchers need constructive criticism 
and suggestions so that this article becomes even better. And also researchers hope that this article can be a reference for readers and future writer.

\section{REFERENCES}

Handayani*, Novia Amarta, and Jumadi Jumadi. 2021. "Analisis Pembelajaran IPA Secara Daring Pada Masa Pandemi Covid-19." Jurnal Pendidikan Sains Indonesia 9(2):217-33. doi: 10.24815/jpsi.v9i2.19033.

Hasanah, Aan, Ambar Sri Lestari, Alvin Yanuar Rahman, and Yudi Irfan Danil. 2020. "Analisis Aktivitas Belajar Daring Mahasiswa Pada Pandemi COVID-19.” Karya Tulis Ilmiah (KTI) Masa Work From Home (WFH) Covid-19 UIN Sunan Gunung Djati Bandung Tahun 2020 4-8.

Ipa, Pembelajaran, Kelas Ix, and Smpn Kota. 2021. “1,2,3,4.” 12:246-53.

Laelasari, Iseu, and Nofita Puspa Dewi. 2020. "Penerapan Pembelajaran Daring Berbasis Whatsapp Group Untuk Siswa Madrasah Ibtidaiyyah Di Tengah Pandemi Covid-19.” Jurnal Penelitian 14(2):249. doi: 10.21043/jp.v14i2.8447.

Much. Solikhin, An Nuril Maulida Fauziah. 2021. “Analisis Kemampuan Berpikir Kritis Siswa Smp Pada Pelajaran Ipa Saat Pembelajaran Daring Selama Pandemi Covid-19.” Pensa EJurnal : Pendidikan Sains 9(2):188-92.

Napaswati. 2020. “Analisis Situasi Pembelajaran IPA Fisika Dengan Metode Daring Di Tengah Wabah COVID-19 (Studi Kasus Peserta Didik MTS DDI Seppange Kabupaten Bone).” Karst Jurnal Pendidikan Fisika Dan Terapannya 3(1):6-12.

Ningrum, Yenni Surfiyanti, and Ria Wulandari. 2020. "Korelasi Implementasi Pembelajaran Ipa Daring Terhadap Literasi Teknologi Siswa Di Kelas Viii Smp." JPPS (Jurnal Penelitian Pendidikan Sains) 10(1):1889. doi: 10.26740/jpps.v10n1.p1889-1898.

Saadjad, Danti Yuliarsi. 2021. "Pengaruh Model Pembelajaran Tgt Melalui Daring Terhadap Hasil Belajar Siswa Mts Negeri 1 Luwuk." Linear : Jurnal Ilmu Pendidikan 5(1):63-72. doi: 10.53090/jlinear.v5i1.95.

Safrawita. 2021. "Meningkatkan Hasil Dan Motivasi Belajar Siswa Pada Pembelajaran Daring Dengan Google Classroom Pada Materi Termokimia Di Kelas Xi Ipa Semester Ganjil Sma Negeri 2 Tanjungpinang Improving Student Learning Outcomes and Motivation By Online Learning With Goo." Zarah 9(1):36-41.

Yunitasari, Ria, and Umi Hanifah. 2020. "Pengaruh Pembelajaran Daring Terhadap Minat Belajar Siswa Pada Masa COVID 19." Edukatif: Jurnal Ilmu Pendidikan 2(3):232-43. doi: 10.31004/edukatif.v2i3.142. 